\title{
Functional Capacity Index: cultural adaptation and measurement of validity and reliability
}

\author{
Functional Capacity Index: adaptação cultural e \\ mensuração da validade e confiabilidade \\ Indice de Capacidad Funcional: adaptación culturaly \\ medición de validez y confiabilidad
}

\section{Marina Peixe Yamada Suely Sueko Viski Zanei ${ }^{b}$ Iveth Yamaguchi Whitaker ${ }^{\mathrm{a}}$}

How to cite this article: Yamada MP, Zanei SSV, Whitaker IY. Functional Capacity Index: cultural adaptation and measurement of validity and reliability. Rev Gaúcha Enferm. 2021;42:e20200091. doi: https://doi. org/10.1590/1983-1447.2021.20200091
Universidade Federal de São Paulo (UNIFESP), Escola Paulista de Enfermagem, Programa de PósGraduação em Enfermagem. São Paulo, São Paulo, Brasil.

'Universidade Federal de São Paulo (UNIFESP), Escola Paulista de Enfermagem, Departamento de Enfermagem Clínica e Cirúrgica. São Paulo, São Paulo, Brasil.

\section{ABSTRACT}

Objective: To carry out a cultural adaptation of the Functional Capacity Index (FCI) into Portuguese and to verify its reliability and validity in traffic accident victims.

Method: Methodological study for cultural adaptation of the FCI. Reliability and validity were verified in a convenience sample of traffic accident victims, in São Paulo city. Data from the patient's medical record were collected retrospectively in 2015. Reliability verified by Cronbach's alpha coefficient and validity by Spearman's correlation and Mann-Whitney test.

Results: The FCl in Portuguese was applied to 50 traffic accident victims. The internal consistency reached Cronbach's alpha values $>0.70$. The $\mathrm{FCl}$ correlated with the Katz index, did not correlate with the severity of trauma and the $\mathrm{FCl}$ of trauma patients was higher compared to those without trauma.

Conclusion: The FCl in Portuguese showed satisfactory internal consistency, allowing the measurement of functional capacity, discriminating against people with and without traumatic injuries

Keywords: Translating. Validation study. Activities of daily living. Wounds and injuries. Accidents, traffic.

\section{RESUMO}

Objetivo: Realizar adaptação cultural do Functional Capacity Index (FCI) para língua portuguesa e verificar sua confiabilidade e validade em vítimas de acidente de trânsito.

Método: Estudo metodológico para adaptação cultural do FCl. Confiabilidade evalidade foram verificadas em amostra de conveniência de acidentados de trânsito, no município de São Paulo. Dados do prontuário do paciente foram coletados retrospectivamente em 2015. Confiabilidade verificada pelo coeficiente alfa de Cronbach e validade pela correlação de Spearman e teste de Mann-Whitney.

Resultados: $0 \mathrm{FCl}$ em português foi aplicado em 50 vítimas de acidente de trânsito. A consistência interna alcançou valores de alfa de Cronbach >0,70. 0 FCl correlacionou com índice de Katz, não correlacionou com a gravidade do trauma e o FCl de pacientes de trauma foi superior em comparação aos sem trauma.

Conclusão: 0 FCl em português mostrou consistência interna satisfatória, permitindo mensurar a capacidade funcional, discriminando pessoas com e sem lesões traumáticas.

Palavras-chave: Tradução. Estudo de validação. Atividades cotidianas. Ferimentos e lesões. Acidentes de trânsito.

\section{RESUMEN}

Objetivo: Realizar adaptación cultural del Índice de Capacidad Funcional (FCI) al portugués y verificar su fiabilidad y validez en víctimas de accidentes de tráfico.

Método: Estudio metodológico para adaptación cultural de FCl. Fiabilidad y validez se verificaron en muestra de conveniencia de víctimas de accidentes de tránsito, en la ciudad de São Paulo. Datos del registro del paciente se recopilaron retrospectivamente en 2015. Fiabilidad verificada por coeficiente alfa de Cronbach y validez por correlación de Spearman y prueba de Mann-Whitney.

Resultados: $\mathrm{FCl}$ en portugués se aplicó a 50 víctimas de accidentes de tránsito. Consistencia interna alcanzó valores alfa de Cronbach $>0,70$. FCI se correlacionó con índice de Katz, no se correlacionó con gravedad del trauma y FCl de pacientes con trauma fue mayor en comparación con aquellos sin trauma.

Conclusión: FCl en portugués mostró consistencia interna satisfactoria, permitiendo medir capacidad funcional, discriminando personas con y sin lesiones traumáticas.

Palabras clave: Traducción. Estudio de validación. Actividades cotidianas. Heridas y traumatismos. Accidentes de tránsito. 


\section{INTRODUCTION}

Traffic accidents (TA) are responsible for the high mortality and morbidity of the tens of millions of people with non-fatal injuries with temporary or permanent disability ${ }^{(1)}$. The impact of traumatic injuries on activities of daily living (ADL) can highlight the consequences of trauma for the patient, family and society, in addition to the cost of hospital care and rehabilitation ${ }^{(2-3)}$.

The individual's ability to perform activities that allow them to take care of themselves and live independently is defined as functional capacity (FC). Thus, disability is characterized by a deficiency in functional performance, that is, in the performance of $\mathrm{ADL}^{(4)}$. Generic and specific tool have been developed to objectively measure FC. For trauma patients, there are tool that assess physical function in order to identify deficits (disability and impairment) and those that assess health status and quality of life covering physical, psychological, emotional and social aspects ${ }^{(5)}$.

The Functional Capacity Index (FCl) was developed and validated in 1996 in the United States of America and available only in English language ${ }^{(6)}$. It is a specific tool to assess physical and cognitive functions after trauma, based on the concept of $F C^{(6,7)}$. The construct of FC that underlies the $\mathrm{FCl}$ is the individual's ability to perform certain important tasks for the everyday life, being defined only in physical and cognitive terms, without including psychosocial aspects ${ }^{(6-7)}$.

Considering the scope of the $\mathrm{FCl}$ to assess the FC of patients who suffered non-fatal traumatic injuries and the importance of analyzing and monitoring the impairment and the progress of the physical and cognitive functionality of trauma victims in Brazil, it was decided to perform the cultural adaptation of Functional Capacity Index (FCl) to Portuguese and verify its reliability and validity in traffic accident victims.

\section{METHOD}

This methodological study on cultural adaptation and validation of the $\mathrm{FCl}$ in Brazilian Portuguese was carried out after the authorization granted by the author of the tool and approval by the Research Ethics Committees of the Universidade Federal de São Paulo - Unifesp (CAAE: 31111014.4.0000.5505 project approval No.: 674,527) and the Municipal Health Office of São Paulo (CAAE: 31111014.4 .3001 .0086 project approval No.: 719.484). All participants signed the Free and Informed Consent Form.

\section{Functional Capacity Index}

The $\mathrm{FCl}$ makes it possible to assess the extent of limitations or reduced capacity in traffic accident victims with traumatic injuries, one year after hospital discharge. Thus, it allows monitoring the impairment and progress of physical and cognitive functionality during rehabilitation, assessing costs and social burden resulting from impaired functional performance, analyzing the epidemiology of disabilities resulting from traumatic injuries for the application of preventive actions, control and reduction of injuries ${ }^{(8-9)}$.

The dimensions that compose the $\mathrm{FCl}$ are: eating, sexual function, excretory function, ambulation, hand and arm movement, bending/lifting, visual function, auditory function, speech and cognitive function. Each dimension has three to six levels of functionality that discriminate against measurable differences. Capacity levels are classified by letters with "a" indicating perfect functionality and "b / c / d / e / $\mathbf{f}^{\prime \prime}$ indicating different levels of impairment of functionality until total disability. The combination of the letters, of each dimension, defines the "profile" of the limitation and allows to verify the progress, the stabilization or the worsening of the FC in different time intervals. The ten dimensions of the $\mathrm{FCl}$ compose the questions about the assessment of functional capacity.

The assessment of the set of limitations, expressed by an overall $\mathrm{FCl}$ score, was developed from the weighting of the dimensions and values for each level of functionality that reflected the impact of the commitment on a daily basis. In each dimension, the best level of functionality was considered zero and the worst, 100 points. The assignment of values to the intermediate levels of functionality was carried out by a group of 114 representatives, from different segments of the population, with or without experience in limiting FC, to judge the likely impact of each level on daily life. The global $\mathrm{FCl}$ score results from the mathematical operation between the dimension weights and the values of the levels of functionality using the formula:(6)

\section{$\mathrm{FCl}=1-\Pi\left(1-\mathrm{w}_{\mathbf{i}} \mathbf{u}\left(\mathbf{x}_{)}\right)\right)$}

Where: $w_{i}=$ weight of the dimension and $u_{i}\left(x_{i}\right)=$ value of the dimension level

\section{Cultural Adaptation Process}

The cultural adaptation of the $\mathrm{FCl}$ was carried out considering the stages of translation, synthesis, back-translation, review by a committee of experts and pre-test ${ }^{(10)}$. The 
translation was carried out independently by two bilingual Brazilians fluent in English, called translators (T1 and T2). The objectives of the translation and the purpose of the tool were informed to the health area translator $(\mathrm{T} 1)$ with the intention of producing a more equivalent translation in technical terms with the original tool. To the lay translator (T2), neither the objectives of the study nor the purpose of the index were informed to obtain a translation compatible with the language of the general population ${ }^{(10)}$. The original and translated versions were compared and analyzed concurrently by a language professor and a researcher with experience in translation and adaptation of tools for consensus and obtaining the translated version (TV).

For the back-translation, the TV was delivered to two other professional bilingual translators, one Brazilian (RT1) and one North American (RT2), who worked independently. The back-translated version (BTV) resulted from the consensus of the same two professionals from the previous stage.

The analysis of the equivalence of the translated tool with the original was carried out in a face-to-face meeting by a Committee of Experts with six members: a physician with a master's degree and experience of more than five years in rehabilitation and trauma; a Portuguese/English language teacher with a university degree, a doctorate degree and experience of more than five years in teaching; two nurses with doctoral degrees and researchers with five years or more of experience in cultural adaptation and concept analysis; a nurse with a doctorate and trauma researcher with more than five years of experience; and, a nurse with more than five years of experience in intensive care and trauma. The original version of the $\mathrm{FCl}$, the TV and the BTV were delivered to the experts for the final version of the tool in Portuguese. The members analyzed the semantic, idiomatic, cultural and conceptual equivalences for the final version ${ }^{(10)}$. After this stage, the pre-test was performed to check the understanding of the terms of the translated version in 30 patients $^{(10)}$.

\section{Measurement of Reliability and Validity}

The reliability and validity of the $\mathrm{FCl}$ in Portuguese were carried out in a convenience sample with people who had a traffic accident, over 18 years of age, attended and admitted to the University Hospital/Unifesp, who were discharged from the hospital a year ago. Traffic accident victims without anatomical injuries or who were discharged in the emergency room (ER) were not included in the sample. The selection of patients was carried out based on the list of hospitalizations of the ER from March/2014, going back to October/2013. From the total of 4,278 hospitalizations in the period, only
278 patients treated at the ER had digitalized files and the reason for the admission could be verified. From these, 112 were related to traffic accidents and their medical records were consulted. Due to the impossibility of telephone contact and/or incorrect data in the medical record, a convenience sample of 50 patients was constituted. Data collection was carried out from March to June 2015, in a specific form with identification data, sociodemographic data (age, gender and schooling), date of the event, anatomical injuries and the translated FCl.

The $\mathrm{FCl}$ was applied in an interview via telephone call with recording, as in the original study ${ }^{(6-7)}$. In the telephone contact, initially, the researcher introduced herself and read the informed consent form. After the patient's acceptance to participate in the research, each dimension and its respective levels were read, being repeated whenever necessary.

The reliability of the $\mathrm{FCl}$ in Portuguese was verified by analyzing the internal consistency ${ }^{(11)}$. To verify whether the tool was congruent with the properties of the object to be measured, the concurrent criterion validity and the discriminant and convergent construct were analyzed ${ }^{(11)}$. In the validity of the concurrent criterion, it was verified a correlation between the scores of the translated tool and scores of another similar measure, considering it as the gold standard, which assesses the individual's independence to perform the $A D L$, the Index of Independence in Activities of Daily Living - Katz Index ${ }^{(12)}$, that is, whether the results of the $\mathrm{FCl}$ corresponded to those of the Katz Index ${ }^{(11)}$.

For the analysis of the discriminant construct validity, that is, to verify if the $\mathrm{FCl}$ construct is not unduly related to the construct it should diverge from ${ }^{(11)}$, in addition to the group of traffic accident patients ("injured" group), another group of equal size and with no previous history of trauma ("non-injured" group) was interviewed. These people were registered at the Primary Healthcare Unit with the Family Health Strategy model, in the southeastern region of the city of São Paulo. The selection criteria were to be over 18 years old and not to have diseases that compromised FC (e.g. congestive heart failure, stroke, Parkinson's disease, Alzheimer's and dementia). The selection of the non-injured group considered individual pairing by gender, age ( 5 years more or less than the patients in the injured group) and schooling. The study objectives were presented to the research participants and the $\mathrm{FCl}$ was applied by telephone contact.

For the convergent construct validity ${ }^{(11)}$, the trauma severity, measured with the Injury Severity Score (ISS), was used as a related construct to verify its correlation with the resulting FC one year after the traffic accident. The correlation was performed to verify that the greater the trauma severity, 
the greater the impairment of FC. The ISS is an anatomical index widely used to determine the severity of trauma by correlating it with survival and mortality. The ISS calculation is based on the severity of three most serious injuries in different body regions. The severity of injuries is defined in the dictionary of the Abbreviated Injury Scale (AIS), whose AIS severity levels range from 1 (minor), 2 (serious), 3 (moderate), 4 (severe), 5 (critical) to 6 (potentially fatal). The severity of the trauma is proportional to the increase in the ISS score, which ranges from 1 to $75^{(13)}$.

For the analysis of the degree of agreement between the experts, the Content Validity Index (CVI) was used, considering values above $90.0 \%$ to be acceptable ${ }^{(11)}$. The reliability of the $\mathrm{FCl}$ was performed with the Cronbach's alpha coefficient, considering an alpha value above $0.7(a>0.7)$ as the minimum acceptable to state that the instrument is reliable $\mathrm{e}^{(11,14)}$. For the concurrent criterion validity ( $\mathrm{FCl}$ scores versus Katz index scores) and the convergent construct validity ( $\mathrm{FCl}$ scores versus ISS scores), the Spearman correlation test was applied. To verify homogeneity between the injured and non-injured groups, the Student's t-test or Mann-Whitney test was used for continuous variables and chi-square test for categorical variables. The analysis of the discriminant construct validity was performed using the Mann-Whitney test, comparing the rank of the $\mathrm{FCl}$ scores derived from the responses of the injured and non-injured group members regarding their functional capacity. The level of statistical significance considered in the analyzes was 5\%.

\section{RESULTS}

In the translated versions, eight discordant items were observed in the dimensions of excretory function, bending/lifting, speech, and cognitive function. The consensus on the discordant items was easily reached, as they were synonymous words and different styles of writing without changing the meaning of the text, thus defining the TV. In BTV, six discordant items in the dimensions of ambulation, auditory function and visual function were identified, but the different words had meanings similar to the original ones. The analysis of the BTV indicated good quality of the translated versions and the synthesis.

In the verification of semantic, idiomatic, cultural and conceptual equivalences by the Committee of Experts, from the total of 58 items analyzed (title, dimensions and levels of functionality), 28 (48.3\%) had an agreement rate lower than $90.0 \%$. At the second meeting of the Committee, 53 items (91.4\%) reached a consensus above $90.0 \%$ and five (8.6\%) did not reach the pre-established agreement rate, due to the disagreement of an expert. Despite this, the text defined by the majority of the members of the Committee prevailed.
The Portuguese denomination of the $\mathrm{FCl}$ was Índice de Capacidade Funcional. However, in order to maintain an internationally recognized language, the English name and the acronym $\mathrm{FCl}$ were maintained. The products of the cultural adaptation process were sent to the $\mathrm{FCl}$ author.

In the pre-test stage, the interviewees reported that the meaning was clearly understood after reading each level of the dimensions and suggested that the word "locomotion" be mentioned in parentheses in the ambulation dimension and the words "bowel and/or bladder function" were presented in parentheses in the excretory function dimension.

The final version of the $\mathrm{FCl}$ in Portuguese is shown in Figure 1.

Reliability and validity were verified in a sample of 50 traffic accident victims with a mean age of 35 years (SD 12.8), 60.0\% were young adults aged between 18 and 34 years, $88.0 \%$ male and $50.0 \%$ with complete/incomplete high school education. Most patients (62.0\%) suffered a motorcycle accident and were hospitalized for 2 to 14 days (62.0\%). The most affected body regions were the lower limbs (26.3\%) and the head (16.0\%), with $48.0 \%$ of the injuries classified as moderate severity, according to the AIS. The ISS indicated global trauma severity level as mild and moderate in $82.0 \%$ of the patients.

Table 1 shows that Cronbach's Alpha values for the FCl dimensions were above 0.7 , contributing in a similar way to the total value of the tool's reliability, which proved to be satisfactory.

Table 1 - Internal consistency of the FCl translated into Portuguese, São Paulo/SP, 2015

\begin{tabular}{lc} 
Dimension & Cronbach's Alpha \\
\hline Excretory function & 0.759 \\
Eating & 0.758 \\
Sexual Function & 0.730 \\
Ambulation & 0.731 \\
Hand/Arm Movement & 0.798 \\
Bending/lifting & 0.746 \\
Speech & 0.773 \\
Auditory function & 0.798 \\
Visual function & 0.797 \\
Cognitive function & 0.760 \\
\hline Total & 0.786 \\
\hline
\end{tabular}

Source: Research data, 2015 


\begin{tabular}{|c|c|c|c|c|c|c|}
\hline \multirow{2}{*}{ Dimension (weight) } & \multicolumn{6}{|c|}{ Dimension levels (value) } \\
\hline & $\mathbf{A}$ & B & C & D & $E$ & $F$ \\
\hline $\begin{array}{l}\text { Excretory function } \\
\text { (bowel and/or bladder } \\
\text { functioning) } \\
(0.740)\end{array}$ & $\begin{array}{l}\mathrm{NL}^{*} \\
(0.0)\end{array}$ & $\begin{array}{l}\text { Small difficulty in controlling } \\
\text { the bowel and / or bladder. } \\
(43.1)\end{array}$ & $\begin{array}{c}\text { Moderate } \\
\text { incontinence, losses } \\
\text { more than once a } \\
\text { week, but not } \\
\text { everyday. (74.6) }\end{array}$ & $\begin{array}{l}\text { Severe } \\
\text { incontinence, } \\
\text { losses almost } \\
\text { everyday. } \\
(100.0)\end{array}$ & & \\
\hline $\begin{array}{l}\text { Eating } \\
(0.752)\end{array}$ & $\begin{array}{l}\mathrm{NL}^{*} \\
(0.0)\end{array}$ & $\begin{array}{l}\text { Dietary restrictions or the } \\
\text { need for special food } \\
\text { preparations due to } \\
\text { difficulties in chewing, } \\
\text { swallowing, or digesting. } \\
\text { (38.2) }\end{array}$ & $\begin{array}{l}\text { Need for a tube for } \\
\text { eating and/or } \\
\text { gastronomy. (100.0) }\end{array}$ & & & \\
\hline $\begin{array}{l}\text { Sexual Function } \\
(0.457)\end{array}$ & $\begin{array}{l}\mathrm{NL}^{*} \\
(0.0)\end{array}$ & $\begin{array}{l}\text { Small difficulty due to } \\
\text { physical limitations. (49.7) }\end{array}$ & \begin{tabular}{|c|}
$\begin{array}{c}\text { Great difficulty due to } \\
\text { physical limitations. } \\
(100.0)\end{array}$ \\
\end{tabular} & & & \\
\hline $\begin{array}{l}\text { Ambulation } \\
\text { (locomotion) } \\
(0.666)\end{array}$ & $\begin{array}{l}\mathrm{NL}^{*} \\
(0.0)\end{array}$ & $\begin{array}{l}\text { Independent, without the } \\
\text { need for devices; can walk } \\
\text { at least } 140 \text { meters (+/- a } \\
\text { block and a half) without } \\
\text { device or help from another } \\
\text { person, but has difficulty } \\
\text { standing for long periods, } \\
\text { running or walking quickly. } \\
(21.8)\end{array}$ & $\begin{array}{c}\text { Independent, but } \\
\text { needs the help of } \\
\text { devices; can walk at } \\
\text { least } 140 \text { meters, but } \\
\text { only with the help of } \\
\text { devices; it may take a } \\
\text { little longer than } \\
\text { expected. (45.6) }\end{array}$ & $\begin{array}{l}\text { Can walk at } \\
\text { least } 140 \\
\text { meters, but } \\
\text { only with the } \\
\text { help of } \\
\text { someone (with } \\
\text { or without a } \\
\text { device). (68.5) }\end{array}$ & $\begin{array}{l}\text { Can walk less } \\
\text { than } 140 \\
\text { meters, with or } \\
\text { without help } \\
\text { from another } \\
\text { person and/or } \\
\text { device. (80.6) }\end{array}$ & $\begin{array}{l}\text { Difficulty walking } \\
\text { at least } 15 \text { meters } \\
\text { or cannot even } \\
\text { walk. }(100.0)\end{array}$ \\
\hline $\begin{array}{c}\text { Hand/Arm Movement } \\
(0.750)\end{array}$ & $\begin{array}{l}\mathrm{NL}^{*} \\
(0.0)\end{array}$ & $\begin{array}{c}\text { Difficulty holding or moving } \\
\text { small objects; without } \\
\text { difficulty with large objects. } \\
(31.0)\end{array}$ & $\begin{array}{l}\text { Difficulty holding or } \\
\text { moving small and } \\
\text { large objects. (57.9) }\end{array}$ & $\begin{array}{l}\text { Difficulty lifting } \\
\text { one or both } \\
\text { arms above } \\
\text { your head; you } \\
\text { may have little } \\
\text { difficulty } \\
\text { moving large } \\
\text { objects. (54.3) } \\
\end{array}$ & $\begin{array}{l}\text { Complete or } \\
\text { nearly } \\
\text { complete loss } \\
\text { of function in } \\
\text { only one of the } \\
\text { arms. (81.0) }\end{array}$ & $\begin{array}{l}\text { Complete or } \\
\text { almost complete } \\
\text { loss of function of } \\
\text { both arms. } \\
(100.0)\end{array}$ \\
\hline Bending/lifting (0.494) & $\begin{array}{l}\mathrm{NL}^{*} \\
(0.0)\end{array}$ & $\begin{array}{l}\text { Difficulty in bending and } \\
\text { lifting } 25 \mathrm{~kg} \text {; without difficulty } \\
\text { lifting } 5 \mathrm{~kg} .(29.5)\end{array}$ & $\begin{array}{l}\text { Difficulty in bending } \\
\text { and lifting } 5 \mathrm{~kg} \text {; but } \\
\text { can do it. }(64.6)\end{array}$ & $\begin{array}{l}\text { Unable to bend } \\
\text { and lift } 5 \mathrm{~kg} . \\
(100.0)\end{array}$ & & \\
\hline Speech (0.685) & $\begin{array}{l}\mathrm{NL}^{*} \\
(0.0)\end{array}$ & $\begin{array}{l}\text { Small difficulty in everyday } \\
\text { speech but can be } \\
\text { understood by everyone. } \\
(29.6)\end{array}$ & $\begin{array}{c}\text { Great difficulties in } \\
\text { everyday speech; it } \\
\text { can be understood } \\
\text { only by people who } \\
\text { know him well. (65.6) }\end{array}$ & $\begin{array}{l}\text { Need help with } \\
\text { a voice } \\
\text { amplifier to } \\
\text { speak or can't } \\
\text { speak. (100.0) }\end{array}$ & & \\
\hline $\begin{array}{l}\text { Auditory function } \\
(0.348)\end{array}$ & $\begin{array}{l}\mathrm{NL}^{*} \\
(0.0)\end{array}$ & $\begin{array}{l}\text { Small difficulty in hearing but } \\
\text { only when the conditions are } \\
\text { not ideal; do not need a } \\
\text { hearing aid. (19.6) }\end{array}$ & $\begin{array}{c}\text { Moderate difficulty } \\
\text { hearing in everyday } \\
\text { conditions; do not } \\
\text { need a hearing aid. } \\
\text { (36.5) }\end{array}$ & $\begin{array}{c}\text { Severe } \\
\text { difficulty } \\
\text { hearing in } \\
\text { everyday } \\
\text { conditions; } \\
\text { usually requires } \\
\text { a hearing aid. } \\
(66.8) \\
\end{array}$ & $\begin{array}{l}\text { Profound loss } \\
\text { or complete } \\
\text { loss of hearing; } \\
\text { not treatable. } \\
(100.0)\end{array}$ & \\
\hline $\begin{array}{l}\text { Visual function } \\
\quad(0.413)\end{array}$ & $\begin{array}{l}\mathrm{NL}^{*} \\
(0.0)\end{array}$ & $\begin{array}{c}\text { Double vision, without or } \\
\text { with little difficulty to read } \\
\text { small letters, drive or } \\
\text { perform activities of daily } \\
\text { living (even with } \\
\text { glasses/contact lenses). } \\
\text { (47.3) }\end{array}$ & $\begin{array}{l}\text { Small difficulty in } \\
\text { reading, driving and } \\
\text { performing activities } \\
\text { of daily living (even } \\
\text { with glasses/contact } \\
\text { lenses), without } \\
\text { double vision. (34.7) }\end{array}$ & $\begin{array}{c}\text { Moderate } \\
\text { difficulty in } \\
\text { reading, driving } \\
\text { and performing } \\
\text { activities of } \\
\text { daily living } \\
\text { (even with } \\
\text { glasses/contact } \\
\text { lenses). (51.8) }\end{array}$ & $\begin{array}{c}\text { Severe } \\
\text { difficulty in } \\
\text { reading, driving } \\
\text { and performing } \\
\text { activities of } \\
\text { daily living } \\
\text { (even with } \\
\text { glasses/contact } \\
\text { lenses). (80.3) }\end{array}$ & $\begin{array}{l}\text { Blind with or } \\
\text { without light } \\
\text { perception. } \\
\text { (100.0) }\end{array}$ \\
\hline $\begin{array}{c}\text { Cognitive function } \\
\qquad(1.000)\end{array}$ & $\begin{array}{l}\mathrm{NL}^{*} \\
(0.0)\end{array}$ & $\begin{array}{c}\text { Small difficulty in } \\
\text { reasoning/problem solving, } \\
\text { memory, } \\
\text { concentration/thinking and/or } \\
\text { attention. (26.7) }\end{array}$ & \begin{tabular}{|} 
Moderate difficulty in \\
reasoning/problem \\
solving, memory, \\
concentration/thinking \\
and/or attention; may \\
need help but is \\
independent in \\
activities of daily \\
living. (49.9)
\end{tabular} & $\begin{array}{l}\text { Does not have } \\
\text { to be confined } \\
\text { at home but } \\
\text { can't live alone. } \\
\text { It does not } \\
\text { need } 24 \mathrm{~h} \\
\text { assistance; can } \\
\text { be left alone for } \\
\text { up to } 8 \text { hours. } \\
(78.2)\end{array}$ & $\begin{array}{l}\text { Cannot leave } \\
\text { the house, } \\
\text { cannot live } \\
\text { alone; cannot } \\
\text { be left alone. } \\
(92.5)\end{array}$ & $\begin{array}{c}\text { Severe mental } \\
\text { limitations, } \\
\text { including } \\
\text { vegetative state } \\
\text { (e.g., does not } \\
\text { communicate, } \\
\text { does not respond } \\
\text { to stimuli, does } \\
\text { not understand). } \\
(100.0)\end{array}$ \\
\hline
\end{tabular}

Figure 1 - Final version of the Functional Capacity Index, translated and adapted to Brazilian Portuguese, São Paulo/SP, 2015 
In the concurrent criterion validity, the $\mathrm{FCl}$ values correlated weakly but significantly with the Katz index values $(r=0.387$ and $p=0.006)$, that is, the lower the Katz score, the lower the $\mathrm{FCl}$ value. As for the convergent construct validity, the $\mathrm{FCl}$ values did not correlate with the ISS scores $(r=-0.118$ and $p=0.415)$.
For the discriminant construct validity, the injured and non-injured groups were statistically similar, as shown in Table 2 .

In the analysis of the discriminant construct validity, it was observed that the $\mathrm{FCl}$ values were statistically higher in the injured group compared to the non-injured group (mean $\mathrm{FCl}$ : 35.5 vs 5.6; $p<0.001)$, discriminating them.

Table 2 - Injured and non-injured groups according to the variables age, gender and schooling. São Paulo/SP, 2015

\begin{tabular}{|c|c|c|c|c|}
\hline \multirow[b]{2}{*}{ Variable } & \multicolumn{2}{|c|}{ Group } & Total & \multirow[b]{2}{*}{$\mathbf{p}$} \\
\hline & $\begin{array}{l}\text { Injured } \\
(n=50)\end{array}$ & $\begin{array}{l}\text { Non-injured } \\
\qquad(n=50)\end{array}$ & $(n=100)$ & \\
\hline Age (years) & & & & $0.842^{*}$ \\
\hline mean (SD) & $34(12.8)$ & $34.5(12,1)$ & $34.3(12.4)$ & \\
\hline median (min.; max.) & $30.5(18 ; 75)$ & $30.5(19 ; 74)$ & $30.5(18 ; 75)$ & \\
\hline Gender, n (\%) & & & & $>0.999+$ \\
\hline Female & $6(12)$ & $6(12)$ & $12(12)$ & \\
\hline Male & $44(88)$ & $44(88)$ & $88(88)$ & \\
\hline Schooling, n (\%) & & & & $0.699 \neq$ \\
\hline Elementary (incomplete/complete) & $15(16)$ & $15(4)$ & $30(30)$ & \\
\hline Secondary school (incomplete/complete) & $24(22)$ & $28(12)$ & $52(52)$ & \\
\hline Higher education (incomplete/complete) & $11(8)$ & $7(6)$ & $18(18)$ & \\
\hline
\end{tabular}

\section{DISCUSSION}

The cultural adaptation of the $\mathrm{FCl}$ to obtain the Brazilian version was satisfactory, noting that the patients clearly understood the meaning of the terms presented.

The validation of the $\mathrm{FCl}$ in Portuguese was carried out with a sample of characteristics similar to those of the original tool ${ }^{(6-7)}$, as well as the interviews that were carried out by telephone contact, with approximately the same duration of nine minutes.

In this study, Cronbachıs alpha values of all dimensions were satisfactory $(a>0.7)$, indicating that the $\mathrm{FCl}$ is a stable and reliable tool for use in patients who have suffered a traffic accident. Studies carried out with $\mathrm{FCl}$ have not verified its internal consistency with this coefficient, and it is not possible to compare the results. Further studies applying $\mathrm{FCl}$ to patients with more severe trauma or who have suffered other trauma mechanisms, in addition to face-to-face application, could reveal other al pha values, indicating greater or lesser consistency.

In the concurrent criterion validity, a correlation was observed between the $\mathrm{FCl}$ and the Katz, that is, the lower the commitment of the $\mathrm{FC}$, the greater the independence to perform the ADL. Considering that the sample consisted 
predominantly of patients with mild to moderate trauma, the $\mathrm{FCl}$ score showed that there were patients with little impairment of FC, enabling the return to $\mathrm{ADL}$. Thus, the correlation with the Katz confirmed the FCl's performance in measuring the $\mathrm{FC}$ in the assessed individuals, corroborating the assumption of the concurrent criterion validity.

It is worth remembering that Katz was developed to assess the functional status of the elderly to perform six activities independently ${ }^{(12)}$. Katz has been widely used to assess the individualss independence to perform ADL after hospital discharge, including critical patients ${ }^{(15-16)}$. Despite the correlation between the $\mathrm{FCl}$ and the Katz, fifteen cases of patients with high $\mathrm{FCl}$ scores and Katz scores equal to zero drew attention. Probably, the plausible explanation is because they are patients with limitations in dimensions not covered in the Katz, such as sexual function, ambulation, bending/lifting, hand/arm movement and cognitive function. Although these tools measure similar constructs, they have differences in their components, which may have an impact on the results of the evaluation of their properties.

In the discriminating construct validity, the $\mathrm{FCl}$ distinguished conditions that are recognized as opposed. Some considerations are necessary, because although the groups have been discriminated against, patients who have not suffered traffic accidents may have impaired FC due to comorbidities or age. The results of the $\mathrm{FCl}$ should be analyzed with caution, as the disability may be due to chronic disease and not be the result of traumatic injury. It is important to remember that the definitions of functionality in the assessment of functional status must be observed for both children and the elderly ${ }^{(12-13)}$.

In the convergent construct validity, it was expected that the greater the trauma severity (ISS), the greater the functional impairment $(\mathrm{FCl})$, but the correlation was not found. It is believed that the time difference in the application of each index justifies the lack of correlation between them, since the ISS was calculated from hospital records during hospitalization (acute phase) and the $\mathrm{FCl}$ was applied one year after hospital discharge. The patient's recovery is related to multiple factors, such as the patient's clinical conditions, the structure of the care institution and the post-hospital discharge follow-up, which may compromise the individualss capacity to a lesser or greater extent after one year.

It is important to note that the ISS is an anatomical index used to determine the severity of the trauma based on the potential for immediate threat to life, therefore, it was not developed to predict FC related to post-trauma health. Another aspect to be considered was the predominance of mild, moderate or severe injuries in the sample. An option to check the $\mathrm{FC}$ related to the patients' injuries according to severity, would be to analyze the impairment or the recovery of functionality according to the compromised body region ${ }^{(13)}$.

There are still few studies that exclusively evaluate the FC of people who have suffered a traffic accident and their return to activities, with studies related to health-related quality of life being more common, which can analyze FC as one of the items $s^{(7-9,17-20)}$. This way, due to the small number of articles using the $\mathrm{FCl}$, it is emphasized the importance of applying this tool in different contexts to evaluate and improve the index performance.

\section{CONCLUSIONS}

The cultural adaptation of the $\mathrm{FCl}$, as a tool to measure the FC of traffic accident victims one year after hospital discharge, allowed us to conclude that the application of the translated and adapted version to Brazilian Portuguese showed satisfactory results in terms of internal consisten$c y$, correlation with another index which assesses FC and discrimination of FC between people with and without traumatic injuries.

In order to broaden the analysis of $\mathrm{FCl}$ performance, future research is suggested for application to people with different mechanism of injury, whether contusion, penetrating or burn.

Some limitations found in this study must be reported. First, the research was carried out in a single center, making it difficult to compose the sample with a greater number of patients who suffered a traffic accident, considering the calculation of the sample size at different levels of trauma severity. Second, despite six attempts at telephone contact on different days and times, there was great difficulty in finding patients after one year of hospital discharge, mainly due to the high number of incorrect telephone numbers. It is known that in a few homes there is a landline, most people have a mobile phone, and the number change is relatively frequent, making contact impossible. In addition, research via telephone contact is still little used in Brazil, causing many people to be afraid, refusing to participate. Third, the telephone interview limits the interviewer to the answers he is hearing, and, at times, the interviewee may omit some information or misinterpret; in person, this could be perceived by the interviewer who, consequently, would repeat the question. And, finally, the validation of the translated $\mathrm{FCl}$ construct to analyze its structural model, through confirmatory factor analysis, has not been verified and should be explored in the future.

The contribution of this study was to adapt a specific tool for trauma patients to the Brazilian reality, capable of 
assessing physical and cognitive limitations. It is noteworthy that the impact of trauma on the health of the individual is more comprehensive, with psychosocial consequences for both the trauma victim and their family members. Thus, the $\mathrm{FCl}$ must be associated with other tools, allowing a broader analysis, which goes beyond functional and cognitive recovery, including emotional recovery, as well as their return to society, both determinants of the individual's quality of life.

\section{QREFERENCES}

1. World Health Organization (CH) [Internet]. Geneva: WHO; $2018-2021$ [cited 2019 Apr 21]. Global status report on road safety 2018; [about 1 screen]. Available from: https://www.who.int/violence_injury_prevention/road_safety_status/2018/en/

2. Roshanfekr P, Khodaie-Ardakani MR, Ardakani HMA, Sajjadi H. Prevalence and socio-economic determinants of disabilities caused by road traffic accidents in Iran; a national survey. Bull Emerg Trauma. 2019 [cited 2019 Apr 21];7(1):60-6. Available from: https://www.ncbi.nlm.nih.gov/pmc/articles/PMC6360010/

3. Weijermars W, Bos N, Stipdonk H. Health burden of serious road injuries in the Netherlands. Traffic Inj Prev. 2016;17(8):863-9. doi: https://doi.org/10.1080/ 15389588.2016.1157591

4. Linden M. Definition and assessment of disability in mental disorders under the perspective of the International Classification of Functioning Disability and Health (ICF). Behav Sci Law. 2017;35(2):124-34. doi: https://doi.org/10.1002/bsl.2283

5. Martino C, Russo E, Santonastaso DP, Gamberini E, Bertoni S, Padovani E, etal. Longterm outcomes in major trauma patients and correlations with the acute phase. World J Emerg Surg. 2020;15:6. doi: https://doi.org/10.1186/s13017-020-0289-3

6. Mackenzie EJ, Damiano A, Miller T, Luchter S. The development of the Functional Capacity Index. J Trauma. 1996;41(5):799-807. doi: https://doi. org/10.1097/00005373-199611000-00006

7. MacKenzie EJ, SaccoWJ, Luchter S, Ditunno JF, Staz CF, Gruen GS, etal. Validating the Functional Capacity Index as a measure of outcome following blunt multiple trauma. Qual Life Res. 2002;11:797-808. doi: https://doi.org/10.1023/a:1020820017658

8. McMurry TL, Sherwood C, Poplin GS, Seguí-Gómez M, Crandall J. Implications of functional capacity loss and fatality for vehicle safety prioritization. Traffic Inj Prev. 2015;16 Suppl 2:S140-S145. doi: https://doi.org/10.1080/15389588.2 015.1052875

9. McMurryTL, Poplin GS, Crandall J. Functional recovery patterns in seriously injured automotive crash victims. Traffic Inj Prev. 2016;17 Suppl 1:21-6. doi: https://doi. org/10.1080/15389588.2016.1201202
10. Beaton D, Bombardier C, Guillemin F, Ferraz MB. Recommendations for the cross-cultural adaptation of the DASH \& QuickDASH outcome measures contributors to this document. Toronto: Institute for Work \& Health; 2007 [cited 2019 Apr 21]. Available from: https://www.researchgate.net/profile/ClaireBombardier-2/publication/265000941_Recommendations_for_the_CrossCultural_Adaptation_of_the_DASH_QuickDASH_Outcome_Measures_ Contributors_to_this_Document/links/53fdd6140cf22f21c2f85143/ Recommendations-for-the-Cross-Cultural-Adaptation-of-the-DASH-QuickDASHOutcome-Measures-Contributors-to-this-Document.pdf

11. Souza AC, Alexandre NMC, Guirardello EB. Psychometric properties in instruments evaluation of reliability and validity. Epidemiol Serv Saude. 2017;26(3):649-59. doi: https://doi.org//10.5123/s1679-49742017000300022

12. Lino VTS, Pereira SRM, Camacho LAB, Ribeiro Filho ST, Buksman S. [Cross-cultural adaptation of the Independence in Activities of Daily Living Index (Katz Index)]. Cad Saude Publica. 2008; 24(1):103-12. Portuguese. doi: https://doi.org/10.1590/ S0102-311X2008000100010

13. Association for the Advancement of Automotive Medicine (US). The Abbreviated Injury Scale (AIS): 2005 Revision, Update 2008. Des Plaines, L: AAAM; 2008.

14. Heale R, Twycross A. Validity and reliability in quantitative studies. Evid Based Nurs. 2015;18(3):66-7. doi: https://doi.org/10.1136/eb-2015-102129

15. Vieira RCA, Paiva WS, Oliveira DV, Guirado VMP, Lança EFC, Sousa RMC. Recovery of patients with pure diffuse axonal injury who remained in a coma for 6 hours or more. World Neurosurg. 2018;109:140-6. doi: https://doi.org/10.1016/j.wneu.2017.09.101

16. Mafra JMS, Silva JM, Silveira LTY, Tanaka C, Fu C. Age and severity of disease compromising the functional status recovery of critically ill patients after hospital discharge: an observational study. Br J Med Med Res. 2015;9(2):1-10. doi: https:// doi.org/10.9734/BJMMR/2015/18456

17. Gabbe BJ, Simpson PM, Cameron PA, Ponsford J, Lyons RA, Collie A, etal. Long-term health status and trajectories of seriously injured patients: a population-based Iongitudinal study. PLoS Med 2017;14(7):e1002322. doi: https://doi.org/10.1371/ journal.pmed. 1002322

18. Palmer CS, Cameron PA, Gabbe BJ. A review of the revised Functional Capacity Index as a predictor of 12 month outcomes following injury. Injury. 2017;48(3):591-8. doi: https://doi.org/10.1016/j.injury.2017.01.006

19. Collie A, Simpson PM, Peter A, Ameratunga S, Ponsford J, Lyons RA, etal. Patterns and predictors of return to work after major trauma: a prospective, populationbased registry study. Ann Surg. 2019;269(5):972-8. doi: https://doi.org/10.1097/ SLA.0000000000002666

20. Gabbe BJ, Simpson PM, Harrison JE, Lyons RA, Ameratunga S, Ponsford J, et al. Return to work and functional outcomes after major trauma: who recovers, when, and how well? Ann Surg. 2016;263(4):623-32. doi: https://doi.org/10.1097/ SLA.0000000000001564 
- Authorship contribution:

Marina Peixe Yamada: Conceptualization; Data curation; Formal analysis; Investigation; Methodology; Validation;

Visualization; Writing-original draft; Writing-review \& editing.

Suely Sueko Viski Zanei: Conceptualization; Data curation; Formal analysis; Investigation; Methodology. Iveth Yamaguchi Whitaker: Conceptualization; Data curation; Formal analysis; Investigation; Methodology; Project administration; Supervision; Validation; Writingoriginal draft; Writing-review \& editing.

The authors declare that there is no conflict of interest.

\section{- Corresponding author:}

Marina Peixe Yamada

Email: marina.peixe@yahoo.com.br 